\title{
The influence of $\mathrm{NO}_{x}$ presence on the catalytic $\mathrm{N}_{2} \mathrm{O}$ decomposition over the supported double-promoted cobalt spinel catalyst
}

\author{
Marek Inger $^{1} \cdot$ Jakub Rajewski $^{1}$ (D) Monika Ruszak ${ }^{1} \cdot$ Marcin Wilk $^{1}$
}

Received: 29 October 2018 / Accepted: 18 March 2019 / Published online: 25 March 2019

(C) The Author(s) 2019

\begin{abstract}
The supported double-promoted cobalt spinel catalyst has been tested for $\mathrm{N}_{2} \mathrm{O}$ decomposition in the model and real gas streams (tail gas) from nitric acid plant. Activity tests carried out in the model gas stream showed a high activity of the developed supported catalyst. However, during catalytic investigations performed under real industrial conditions it was found that this catalyst is very sensitive to $\mathrm{NO}_{x}$ poisoning. The negative influence of these oxides is visible even at their low concentration. However, the stability tests performed in real nitric acid plant gas streams showed that the developed catalyst preserves its initial activity for at least 40 days. Therefore, the authors propose to apply it in a dual-bed catalytic system consisting of deNO $\mathrm{x}_{\mathrm{x}}$ and de $\mathrm{N}_{2} \mathrm{O}$ catalyst beds. At the first stage, tail gas is purified from $\mathrm{NO}_{\mathrm{x}}$ in the $\mathrm{NH}_{3}-\mathrm{SCR}$ process in the presence of commercial catalyst and at the second stage, catalytic decomposition of $\mathrm{N}_{2} \mathrm{O}$ into $\mathrm{N}_{2}$ and $\mathrm{O}_{2}$ takes place over the developed supported cobalt spinel catalyst. The deNO ${ }_{x}$ catalyst bed applied in the proposed dual-bed catalytic system allowed for the complete conversion of $\mathrm{NO}_{x}$ from the tail gases. After installation of the supported cobalt spinel catalyst downstream of the deNO ${ }_{x}$ catalyst bed, a significant increase in $\mathrm{deN}_{2} \mathrm{O}$ catalyst activity in the real tail gas stream was observed. Under optimal conditions, this system $\left(F=150 \mathrm{~L} / \mathrm{h} ; T=425-450{ }^{\circ} \mathrm{C}\right)$ allowed for the complete reduction of $\mathrm{N}_{2} \mathrm{O}$ emission. It is shown that the proposed catalytic system is robust and allows to obtain high conversions of both $\mathrm{NO}_{x}$ and $\mathrm{N}_{2} \mathrm{O}$.
\end{abstract}

\section{Graphical abstract}

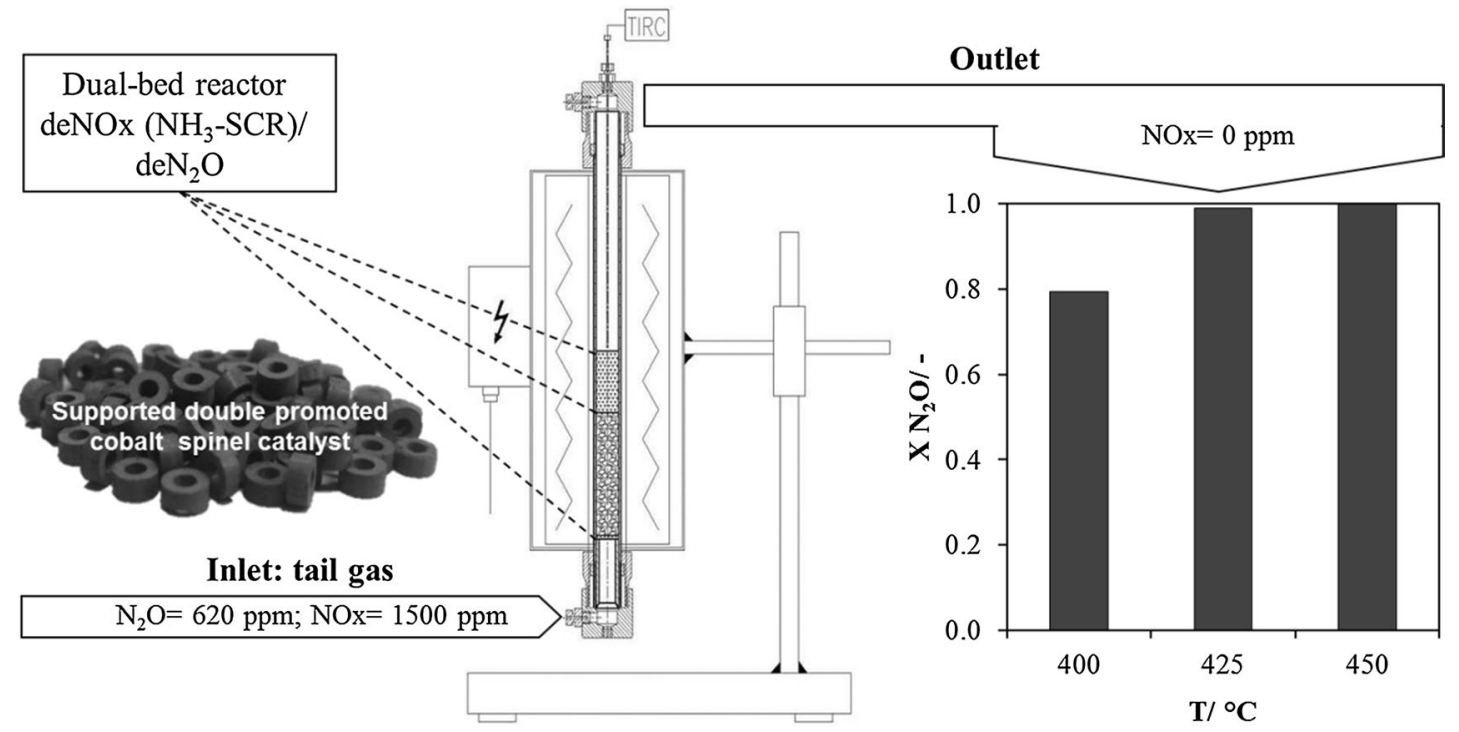

Keywords Low-temperature $\mathrm{N}_{2} \mathrm{O}$ decomposition $\cdot$ Supported cobalt spinel catalyst - Dual-bed catalytic reactor

This work was presented at the 14th Pannonian International

Symposium on Catalysis held in Horný Smokovec, Slovakia on

3-7 September 2018.

Extended author information available on the last page of the article 


\section{Introduction}

Nitric acid plants constitute one of major industrial sources of nitrous oxide (I) where it is formed as a byproduct in the catalytic oxidation of ammonia on $\mathrm{Pt}-\mathrm{Rh}$ gauzes. The formed nitrous oxide (I) does not take part in any technological reactions of nitric acid production process. Therefore, its total amount being formed in ammonia reactor is practically transferred to tail gases and is emitted to the atmosphere. Its final concentration depends on plant-operating parameters and it can reach the level of 2000 ppm (Pérez-Ramirez et al. 2003). Directive (2010) imposes on EU members, the obligation to reduce the emission of this gas below $150 \mathrm{ppm}$ for existing plants and below 100 ppm for new nitric acid plants. Meeting the requirements related to $\mathrm{N}_{2} \mathrm{O}$ emissions, especially in existing nitric acid plants, needs catalytic processes to be implemented in the production technology. The analysis of operating parameters of nitric acid plant indicates that the process can be carried out in nitrous gas stream $\left(T=750-940{ }^{\circ} \mathrm{C}\right)$ and/or tail gas stream $\left(T=200-450{ }^{\circ} \mathrm{C}\right)$ (Pérez-Ramirez et al. 2003).

In studies of removing nitrous oxide (I) from tail gases, numerous catalytic systems were investigated (Kapteijn et al. 1996). Generally, they can be categorized into three groups: modified zeolites (Cheng et al. 2012; Hussain et al. 2012; Zhang et al. 2012; Melian-Cabrera et al. 2018), supported catalyst (Shen et al. 2009; Karaskova et al. 2012; Rico-Pérez and Bueno-López 2014) and modified oxide catalysts (Pasha et al. 2009; Karásková et al. 2010; Zabilskiy et al. 2015).

The analysis of literature reports implies that cobalt oxide is one of the most active substances in catalysts for $\mathrm{N}_{2} \mathrm{O}$ decomposition. Studies of decomposition process of $\mathrm{N}_{2} \mathrm{O}$ from the stream of tail gases with the use of doped spinel catalyst obtained using precipitation method and formed into tablets (Wilk et al. 2009; Inger et al. 2011a, b, 2013) showed that the catalyst is active and stable under industrial conditions (Inger et al. 2014). At the same time, it was found that the reaction rate is limited by internal diffusion resistance. As a result of this fact, a significant internal part of the shape does not take part in the contact process. Bearing in mind a high price of the main raw material, cobalt oxide, the production cost of catalyst may increase radically, making the proposed solution economically ineffective. Therefore, further research was focused on finding such a catalyst formula where its active phase would be the proposed doublepromoted cobalt spinel placed on the support. During the course of studies, most promising supports in terms of their applicability were specified: cordierite monoliths (Grzybek et al. 2015) and aluminum oxide (Grzybek et al. 2017), and the method of placing the active phase on the support and the production technology of the final catalyst formula in pilot scale was developed (Wilk et al. 2016). As a result of studies, it was found that the active phase placed onto support in the amount of $20 \%$ wt. sufficient to obtain highactivity catalyst. Therefore, the mass of costly component of the catalyst was significantly reduced.

A significant limitation for the application of the developed catalyst in the removal of $\mathrm{N}_{2} \mathrm{O}$ from tail gases is its resistance to inhibiting effect of other components, i.e. $\mathrm{H}_{2} \mathrm{O}$, $\mathrm{O}_{2}$, and $\mathrm{NO}_{x}$ in particular. Catalysts containing transition metals (e.g. cobalt, iron) are generally more sensitive to the presence of $\mathrm{NO}_{x}$ in gas stream which can be easily absorbed on their active centers, especially at temperatures $<400{ }^{\circ} \mathrm{C}$ and $\mathrm{NO}_{x}$ can block these active canters for $\mathrm{N}_{2} \mathrm{O}$ decomposition. Therefore, the use of developed catalyst in the industrial nitric acid plants requires a prior reduction of $\mathrm{NO}_{x}$ to the lowest possible level.

The $\mathrm{NO}_{x}$ removal process can be realized by a selective catalytic reduction of $\mathrm{NO}_{x}$ with using $\mathrm{NH}_{3}$ as a reducing agent. The low-temperature $\mathrm{NH}_{3}$-SCR method is successfully and widely used in existing nitric acid plants (Luck and Roiron 1989; Avila et al. 1993). As reported by (PérezRamirez et al. 2000; Kim et al. 2011, 2012), a practical and simple implementation method may be the application of dual-bed catalyst systems to $\mathrm{NO}_{x}$ reduction as well as the removal of harmful byproducts as $\mathrm{N}_{2} \mathrm{O}$, especially in the low-temperature regime.

The aim of the study was to investigate the effect of $\mathrm{NO}_{x}$ presence on the activity of the supported double-promoted cobalt spinel catalyst. Moreover, operating conditions for $\mathrm{deN}_{2} \mathrm{O}$ catalyst in a dual-bed catalytic system were determined, consisting of a deNO $\mathrm{N}_{x}$ and $\mathrm{deN}_{2} \mathrm{O}$ catalyst bed. In this case, in the first bed, the $\mathrm{NO}_{x}$ was removed by $\mathrm{NH}_{3}-\mathrm{SCR}$ process over the commercial catalyst and in the second bed, $\mathrm{N}_{2} \mathrm{O}$ was catalytically decomposed into $\mathrm{N}_{2}$ and $\mathrm{O}_{2}$ over supported cobalt spinel catalyst (Wilk et al. 2016). It is shown that this dual-bed catalytic system is robust and allows to achieve high conversions of both $\mathrm{NO}_{x}$ and $\mathrm{N}_{2} \mathrm{O}$.

\section{Experimental}

\section{Catalyst preparation}

The raw material used to prepare support was the aluminum hydroxide oxide. It was mixed with graphite and plasticizer with the addition of water and then shaped into Raschig rings with the following dimensions: diameter $\times$ length $\times$ hole diameter $=4 \times 2 \times 1 \mathrm{~mm}$. The shaped sample was then dried in the air and calcined at $1400^{\circ} \mathrm{C}$ for $4 \mathrm{~h}$.

Supported cobalt spinel catalyst was prepared by impregnation of $\alpha-\mathrm{Al}_{2} \mathrm{O}_{3}$ support with an aqueous solution of cobalt, zinc and potassium salts. The concentration of salts in the impregnating solution was adjusted to obtain $20 \mathrm{wt} \%$ 
loading of the active phase in the whole mass of supported catalyst. After impregnation of the support, the samples were dried at $120{ }^{\circ} \mathrm{C}$ and then calcined in the air at $450{ }^{\circ} \mathrm{C}$ for $4 \mathrm{~h}$ (Wilk et al. 2016).

\section{The activity tests of the catalyst}

All catalytic tests were performed in a tubular reactor with a diameter $d=25 \mathrm{~mm}$, equipped with a heating mantle and a temperature control unit (Fig. 1). For the activity tests, a model gas mixture $\left(\mathrm{N}_{2} \mathrm{O} / \mathrm{NO} / \mathrm{N}_{2}\right)$ and the real tail gas were used. The model gas contained 1500 or 2000 ppm $\mathrm{N}_{2} \mathrm{O}$, 0-1000 ppm NO and $\mathrm{N}_{2}$ as a balance. Tail gases were taken directly from the pilot nitric acid plant and their compo-

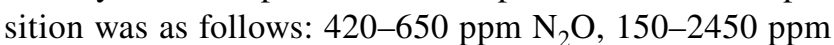
$\mathrm{NO}_{x}, 0.3-0.4$ vol. $\% \mathrm{H}_{2} \mathrm{O}, 1.3-2.2$ vol. $\% \mathrm{O}_{2}$ and $\mathrm{N}_{2}$. The initial concentration of ammonia after mixing with tail gases for SCR process was 0.1 or 0.2 vol. $\%$. All the catalytic tests were performed at the temperature range of $300-450{ }^{\circ} \mathrm{C}$, corresponding to the conditions of a tertiary $\mathrm{N}_{2} \mathrm{O}$ abatement process in the nitric acid plants, at the gas flow within the range of $100-600 \mathrm{Ndm}^{3} / \mathrm{h}$.

In case of activity studies of $\operatorname{deN}_{2} \mathrm{O}$ catalyst with no deNO$_{x}$ catalyst applied, the catalytic bed layer with the volume of approx. $30 \mathrm{~cm}^{3}$ was used, which was placed on the layer of inert bed in the form of aluminum oxide shapes with the volume of $50 \mathrm{~cm}^{3}$. In studies with the application of dual-bed catalytic system, the layer of $\operatorname{deN}_{2} \mathrm{O}$ with the volume of $30 \mathrm{~cm}^{3}$ and the layer of $\mathrm{deNO}_{x}$ with the volume of $50 \mathrm{~cm}^{3}$ were applied.

Measurements of $\mathrm{N}_{2} \mathrm{O}$ conversion at the assumed temperature of ( $T=$ const) were carried out after $10 \mathrm{~min}$ of the moment it was stabilized. The amount of ammonia fed to the reactor during studies of $\mathrm{deN}_{2} \mathrm{O}$ catalyst in dual-bed catalytic system was determined based on the intensity of tail gas flow and the initial concentration of $\mathrm{NO}_{x}$ in these gases. Tail gases before mixing with gaseous $\mathrm{NH}_{3}$ were preheated to the temperature of $300{ }^{\circ} \mathrm{C}$.

All studies were carried out with the use of formed catalysts in the shape that will be used in industrial practice. The composition of the gases (at the inlet and outlet of the reactor) was measured by a Gasmet ${ }^{\mathrm{TM}}$ CX 4000 FTIR Gas Analyzer (Gasmet Technologies).

\section{Results and discussion}

\section{The activity of de $\mathrm{N}_{2} \mathrm{O}$ catalyst}

The results of the activity tests performed in the model gas mixture showed that the developed $\operatorname{deN}_{2} \mathrm{O}$ catalyst has a very high activity in the absence of $\mathrm{NO}_{x}$. At the temperature of $380{ }^{\circ} \mathrm{C}$ and with gas flow amounting to $300 \mathrm{Ndm}^{3} / \mathrm{h}$, the $\mathrm{N}_{2} \mathrm{O}$ conversion above $85 \%$ was achieved. A double decrease of gas flow intensity allowed to achieve almost a $100 \% \mathrm{~N}_{2} \mathrm{O}$ conversion at this temperature (Table 1).

The presence of NO in gas stream causes the shift of temperature window of $\mathrm{deN}_{2} \mathrm{O}$ process towards higher temperatures (Fig. 2) and the temperature increase of decomposition process is directly proportional to NO concentration at the inlet to the reactor. It is particularly visible at temperatures of $300-370{ }^{\circ} \mathrm{C}$. This interdependence is reflected in the temperature difference of a $50 \% \mathrm{~N}_{2} \mathrm{O}$ conversion (Table 2). The increase of NO concentration in gas stream 100 ppm causes temperature increase $T_{50 \%}$ by $30{ }^{\circ} \mathrm{C}$. However, at the temperature above $400{ }^{\circ} \mathrm{C}$, the complete conversion of $\mathrm{N}_{2} \mathrm{O}$ over supported cobalt spinel catalyst was achieved in all measurements, regardless of the initial content of NO in the inlet gas. The inhibiting effect of NO in gas stream may be linked with adsorption of $\mathrm{NO}$ particles on active centers of the catalyst, which contributes to blocking of these centers for $\mathrm{N}_{2} \mathrm{O}$ decomposition. This can be prevented with the increase of $\mathrm{deN}_{2} \mathrm{O}$ process temperature to the level above $400{ }^{\circ} \mathrm{C}$. Such a
Fig. 1 Scheme of the reactor used for the activity tests of supported cobalt spinel catalyst in a single-bed $\left(\mathrm{deN}_{2} \mathrm{O}\right)$ and dualbed $\left[\mathrm{deN}_{2} \mathrm{O} / \mathrm{deNO}_{x}\left(\mathrm{NH}_{3}-\mathrm{SCR}\right)\right]$ catalytic system

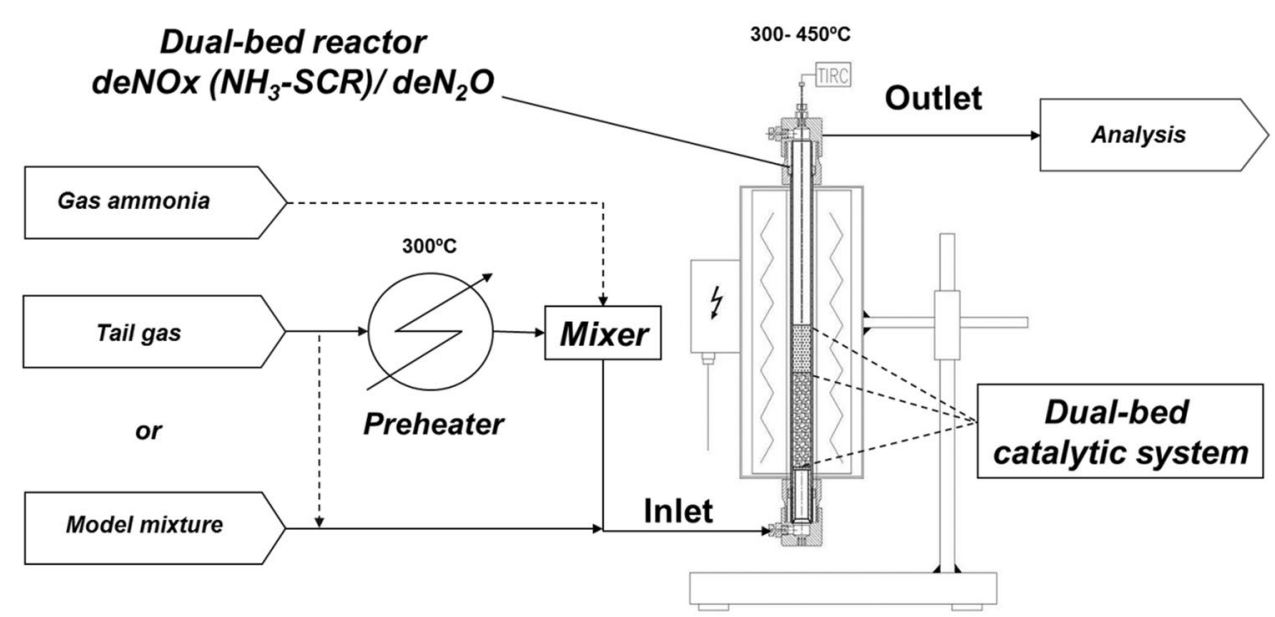


temperature level has a favorable effect on NO desorption from the catalyst surface, making the active surface available for $\mathrm{N}_{2} \mathrm{O}$ decomposition reaction. The reversible nature of poising the cobalt catalyst was described in paper Inger et al. (2011a, b).

During the experiments carried out under real industrial conditions (Table 3) despite the lower $\mathrm{NO}_{x}$ content than in the model gas stream (Table 2), an additional temperature increase $T_{50 \%}$ was observed. For example, for model gas with $\mathrm{NO}_{x}$ concentration $=250 \mathrm{ppm}, T_{50 \%}$ was $335^{\circ} \mathrm{C}$, while in the real tail gases with $\mathrm{NO}_{x}$ concentration $=150 \mathrm{ppm}, T_{50 \%}$ was $380{ }^{\circ} \mathrm{C}$. It can be concluded that other tail gas components $\left(\mathrm{O}_{2}\right.$ and $\left.\mathrm{H}_{2} \mathrm{O}\right)$ can also have a negative effect on activity of the developed catalyst. Therefore, high final conversion of $\mathrm{N}_{2} \mathrm{O}$ can be attained by increasing the temperature reaction and/ or extending the residence time of reaction gas in the catalyst bed (Table 3).

The increase of $\mathrm{NO}_{x}$ concentration at the inlet of the reactor resulted in a decrease of $\mathrm{N}_{2} \mathrm{O}$ conversion, regardless of the gas flow rate. The exception was the results obtained at the lowest measured gas flow rate for which $\mathrm{N}_{2} \mathrm{O}$ conversions observed with the $\mathrm{NO}_{x}$ content of 150 and $650 \mathrm{ppm}$ were at the similar level.

The stability of developed catalyst was also investigated. In Fig. 3, the results of $\mathrm{N}_{2} \mathrm{O}$ decomposition for the fresh and used catalysts (after $500 \mathrm{~h}$ and $1000 \mathrm{~h}$ of operation) are shown. The experimental data are expressed as a function of $\mathrm{N}_{2} \mathrm{O}$ conversion $\left(X_{\mathrm{N}_{2} \mathrm{O}}\right)$ versus temperature. The stability tests $\left(T=350-450^{\circ} \mathrm{C}, F=150 \mathrm{Ndm}^{3} / \mathrm{h}, 5000 \mathrm{GHSV}\right.$, tail gas composition: $600-650 \mathrm{ppm} \mathrm{N} \mathrm{N}_{2} \mathrm{O}, 44-520$ ppm $\mathrm{NO}_{x}, 2.2 \%$ $\mathrm{H}_{2} \mathrm{O}$ and $2.2 \% \mathrm{O}_{2}$ ) showed that the developed catalyst preserves its initial activity for at least 40 days, wherein the $\mathrm{N}_{2} \mathrm{O}$ conversion during this period remains at the level of $>0.95$ for $420{ }^{\circ} \mathrm{C}, 0.62-0.80$ for $400{ }^{\circ} \mathrm{C}$ and $0.34-0.55$ for $380{ }^{\circ} \mathrm{C}$. Differences in conversion curves as presented in Fig. 3 are the result of a large slope of the curves, which is caused by a large increase in the catalyst activity in the temperature range $350-420{ }^{\circ} \mathrm{C}$. Moreover, differences in conversion curves may also result from a small difference in the

Table 1 Comparison of the activity of developed $\operatorname{deN}_{2} \mathrm{O}$ catalyst in a model gas mixture containing 1500 and $2000 \mathrm{ppm} \mathrm{N} \mathrm{N}_{2} \mathrm{O} / \mathrm{N}_{2}$

\begin{tabular}{llllr}
\hline Model gas mixture & & & \\
\hline$F, \mathrm{Ndm}^{3} / \mathrm{h} ; \mathrm{GHSV}$ & $C_{\mathrm{NO}_{x}} \mathrm{ppm}$ & $C_{\mathrm{N}_{2} \mathrm{O}}, \mathrm{ppm}$ & \multicolumn{2}{l}{$\begin{array}{l}\mathrm{N}_{2} \mathrm{O} \text { conver- } \\
\text { sion, } \%\end{array}$} \\
\cline { 3 - 5 } & & & $\frac{T,{ }^{\circ} \mathrm{C}}{}$ \\
\cline { 3 - 5 } & & & 350 & 380 \\
\hline $300 / 10,000$ & 0 & 1500 & & 87.3 \\
$150 / 5000$ & 0 & 1500 & 91.5 & 100.0 \\
$150 / 5000$ & 0 & 2000 & 87.8 & 99.2 \\
\hline
\end{tabular}

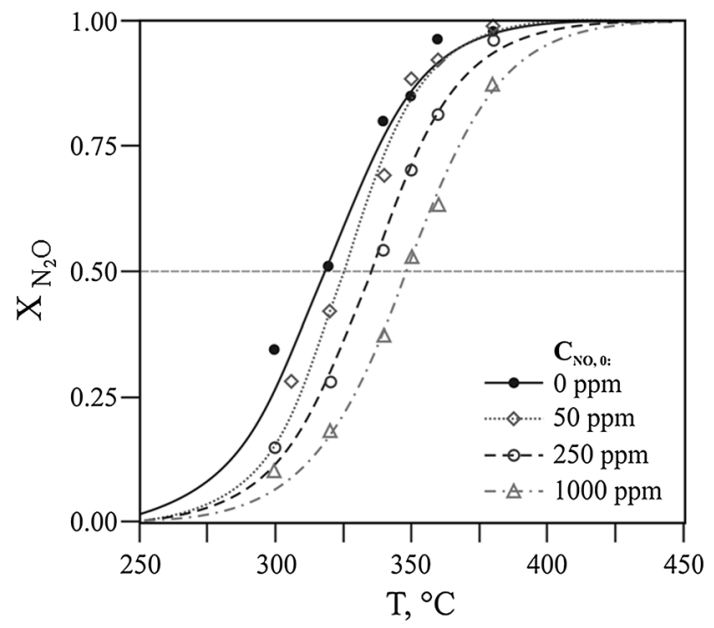

Fig. 2 The effect of $\mathrm{NO}_{x}$ content in a model gas mixture on the $\mathrm{N}_{2} \mathrm{O}$ conversion over supported cobalt spinel catalyst $(\mathrm{NO}=0-1000 \mathrm{ppm}$, $\mathrm{N}_{2} \mathrm{O}=2000 \mathrm{ppm}, F=150 \mathrm{Ndm}^{3} / \mathrm{h} ; 5000$ GHSV)

composition of tail gases or from accuracy of the measurement method $\left(\Delta T_{50 \%} \leq 10{ }^{\circ} \mathrm{C}\right)$.

The results presented above show that the supported double-promoted cobalt spinel catalyst can be applied in the industrial nitric acid installations if prior reduction of $\mathrm{NO}_{x}$ in the tail gas stream to the lowest possible level was carried out. Therefore, further investigations were focused on determining the activity of the developed $\mathrm{deN}_{2} \mathrm{O}$ catalyst in the presence of the second catalyst bed for $\mathrm{NO}_{x}$ reduction using $\mathrm{NH}_{3}$-SCR process.

\section{Dual-bed catalytic system}

The temperature window for selective catalytic reduction falls in the range of $200-450{ }^{\circ} \mathrm{C}$ depending on the type of the catalyst applied. The process efficiency is determined with the amount of $\mathrm{NH}_{3}$ fed into the inlet mixture according to the following reactions:

$$
\begin{aligned}
& \mathrm{NO}+2 / 3 \mathrm{NH}_{3}=5 / 6 \mathrm{~N}_{2}+\mathrm{H}_{2} \mathrm{O}, \\
& \mathrm{NO}_{2}+4 / 3 \mathrm{NH}_{3}=7 / 6 \mathrm{~N}_{2}+2 \mathrm{H}_{2} \mathrm{O} .
\end{aligned}
$$

In the case of initial concentration of the reducing agent about 0.1 vol.\%., low $\mathrm{NO}_{x}$ conversion was observed (Fig. 4a). No ammonia was found at the outlet of the reactor, that the ammonia has completely reacted. It was

Table 2 The temperature of $50 \% \mathrm{~N}_{2} \mathrm{O}$ conversion for different $\mathrm{NO}_{x}$ concentration in the model gas mixture at the inlet of the reactor

\begin{tabular}{lllll}
\hline$C_{\text {NOx }}, \mathrm{ppm}$ & 0 & 50 & 250 & 1000 \\
\hline$T_{50 \%},{ }^{\circ} \mathrm{C}$ & 318 & 325 & 335 & 348 \\
\hline
\end{tabular}


Table 3 The activity of supported catalyst in the form of Raschig rings

\begin{tabular}{|c|c|c|c|c|c|c|c|}
\hline \multirow[t]{3}{*}{$F, \mathrm{Ndm}^{3} / \mathrm{h} ; \mathrm{GHSV}$} & \multirow[t]{3}{*}{$C_{\mathrm{NO}_{x}}, \mathrm{ppm}$} & \multirow[t]{3}{*}{$C_{\mathrm{N}_{2} \mathrm{O}}, \mathrm{ppm}$} & \multicolumn{5}{|c|}{$\mathrm{N}_{2} \mathrm{O}$ conversion, $\%$} \\
\hline & & & \multicolumn{5}{|l|}{$T,{ }^{\circ} \mathrm{C}$} \\
\hline & & & 350 & 380 & 400 & 420 & 450 \\
\hline $150 / 5000$ & 150 & 550 & 23.3 & 49.1 & 80.0 & n.m & n.m. \\
\hline $150 / 5000$ & 650 & 440 & 11.4 & 56.4 & 81.8 & 93.1 & n.m. \\
\hline $150 / 5000$ & 1300 & 510 & 10,8 & 35.3 & 65,7 & 84.8 & n.m. \\
\hline $300 / 10,000$ & 150 & 550 & n.m. & 16.4 & 38.2 & 67.3 & n.m. \\
\hline $300 / 10,000$ & 650 & 440 & n.m. & 9.1 & 27.3 & 52.3 & n.m. \\
\hline $300 / 10,000$ & 1300 & 518 & n.m & 5.4 & 17.0 & 40.2 & n.m. \\
\hline $600 / 20,000$ & 150 & 550 & 0.0 & 0.0 & 3.6 & 11.8 & 46.4 \\
\hline $600 / 20,000$ & 1300 & 550 & 0.0 & 0.0 & 2.7 & 3.6 & 20.0 \\
\hline
\end{tabular}

Measurements of real tail gases. Gase composition: $\mathrm{NO}_{\mathrm{x}}$ and $\mathrm{N}_{2} \mathrm{O}$ concentration in table, $\mathrm{H}_{2} \mathrm{O}: 0.3-0.4$ vol. $\%, \mathrm{O}_{2}: 1.3-2.2$ vol. $\%$ and $\mathrm{N}_{2}$ : rest

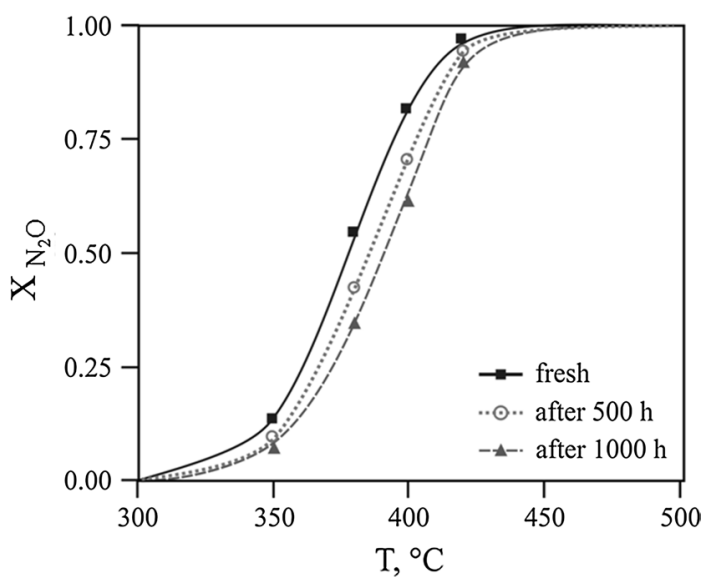

Fig. 3 Conversion curves for the fresh and used supported cobalt spinel catalyst $\left(F=150 \mathrm{Ndm}^{3} / \mathrm{h}, 5000 \mathrm{GHSV}\right)$, tail gas composition: 600-650 ppm $\mathrm{NO}_{x}, 0.3-0.4$ vol.\% $\mathrm{H}_{2} \mathrm{O}, 2.2$ vol.\% $\mathrm{O}_{2}, 440-520 \mathrm{ppm}$ $\left.\mathrm{N}_{2} \mathrm{O}\right)$

concluded that ammonia was deficient. The use of 0.2 vol. $\% \mathrm{NH}_{3}$ excess allowed for the complete $\mathrm{NO}_{x}$ reduction in the temperature range from 250 to $400{ }^{\circ} \mathrm{C}$. However, the presence of ammonia at the outlet of the reactor was noted (Fig. 4b), which means that an excess of ammonia was used in relation to the initial concentration of $\mathrm{NO}_{x}$ $(1480 \mathrm{ppm})$ in tail gases. Limitations of the laboratory system (control of the tail gas and ammonia flow rate) made it impossible to determine the optimal amount of ammonia, which on the one hand would allow to completely reduce $\mathrm{NO}_{x}$, on the other hand, it would not cause ammonia enter into the outlet of the reactor.

Increasing the temperature above $400{ }^{\circ} \mathrm{C}$ caused a rapid drop in the catalyst activity. Furthermore, increasing the temperature above $300{ }^{\circ} \mathrm{C}$ caused the formation of additional $\mathrm{N}_{2} \mathrm{O}$.

As reported by Wang et al. (2015), $\mathrm{N}_{2} \mathrm{O}$ is the major byproduct of the deNO $\mathrm{NH}_{3}$-SCR process, regardless of the type of the catalyst used. In general, there are three main pathways for $\mathrm{N}_{2} \mathrm{O}$ formation during $\mathrm{NH}_{3}$-SCR process (Lietti et al. 1999; Yates et al. 2005; Martín et al. 2007):

$2 \mathrm{NH}_{3}+\mathrm{O}_{2}=\mathrm{N}_{2} \mathrm{O}+3 \mathrm{H}_{2} \mathrm{O}$,

$\mathrm{NO}_{\mathrm{x}}+\mathrm{NH}_{3}+\mathrm{O}_{2} \rightarrow \mathrm{N}_{2} \mathrm{O}+\mathrm{H}_{2} \mathrm{O}$

$3 \mathrm{NO}=\mathrm{N}_{2} \mathrm{O}+\mathrm{NO}_{2}$.

The results shown in the Fig. $4 \mathrm{~b}$ show that the excess of $\mathrm{NH}_{3}$ used in the deNO $\mathrm{NH}_{3}$-SCR process reacts to $\mathrm{N}_{2} \mathrm{O}$ (according to the reactions 3 and 4). The formation of additional amount of $\mathrm{N}_{2} \mathrm{O}$ in the stream of gas leaving the $\mathrm{deNO}_{x}$ catalyst bed is not a problem as nitrous oxide will be decomposed in the next catalytic bed over the developed $\mathrm{deN}_{2} \mathrm{O}$ catalyst. However, in case of the application of excessive amount of ammonia the possibility of ammonia slip at the outlet of reactor is a problem. In the current case, ammonia slip occurred at temperatures lower than $400{ }^{\circ} \mathrm{C}$ whilst with the temperature exceeding this level, ammonia slip was converted into $\mathrm{N}_{2} \mathrm{O}$. Thus, in the proposed dual-bed catalytic system consisting of deNO $\mathrm{N}_{x}$ commercial catalyst and the developed supported $\operatorname{deN}_{2} \mathrm{O}$ catalyst, it is necessary to use the stoichiometric or slightly higher amount of $\mathrm{NH}_{3}$ reducing agent (for a complete $\mathrm{NO}_{x}$ reduction). On the one hand, it will ensure complete $\mathrm{NO}_{x}$ conversion; on the other hand, it will not cause the formation of a large amount of additional $\mathrm{N}_{2} \mathrm{O}$.

During the next stage of the study, $\mathrm{N}_{2} \mathrm{O}$ conversion in the dual-bed catalytic system was investigated under real industrial conditions (tail gas composition: $\mathrm{N}_{2} \mathrm{O}=620 \mathrm{ppm}$, $\mathrm{NO}_{x}=1500 \mathrm{ppm}, \mathrm{O}_{2}=1.35$ vol. $\%, \mathrm{H}_{2} \mathrm{O}=0.30$ vol. $\%$ ). The results of the developed catalyst activity are shown in Fig. 5. The results show that even for the best process conditions $\left(F_{\mathrm{GR}}=300 \mathrm{~L} / \mathrm{h}, T=450{ }^{\circ} \mathrm{C}\right)$ without reducing agent, tested catalytic system allows for a maximum of 
Fig. 4 The process of selective catalytic reduction of $\mathrm{NO}_{x}$ with using $\mathrm{NH}_{3}$ in the presence of the commercial catalyst samples in the case of $\mathbf{a ~} \mathrm{NH}_{3}$ deficiency $(0.1$ vol. \%) and b $\mathrm{NH}_{3}$ excess ( 0.2 vol.\%). Tail gas composition: $\mathrm{N}_{2} \mathrm{O}=500 \mathrm{ppm}$, $\mathrm{NOx}=1480 \mathrm{ppm}, \mathrm{O}_{2}=1.13$ vol. $\%, \mathrm{H}_{2} \mathrm{O}=0.30$ vol. $\%$, $F=600 \mathrm{Ndm}^{3} / \mathrm{h}, 20,000 \mathrm{GHSV}$ (a)
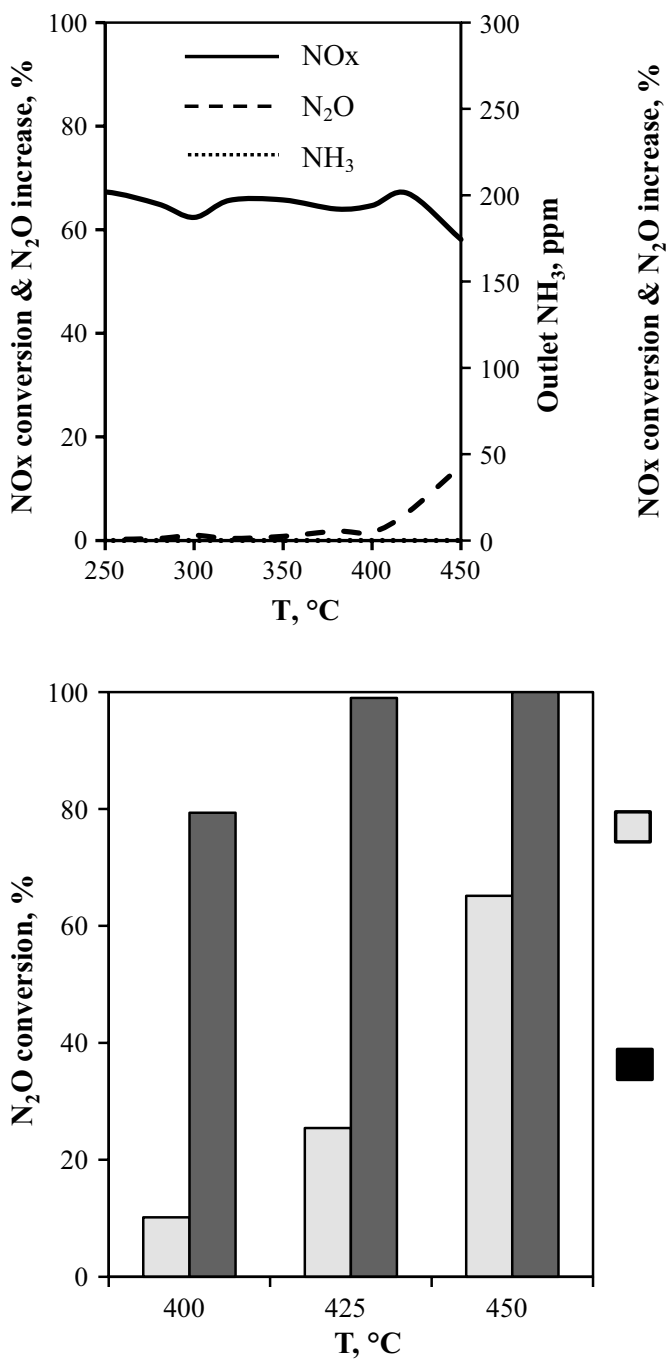

(b)

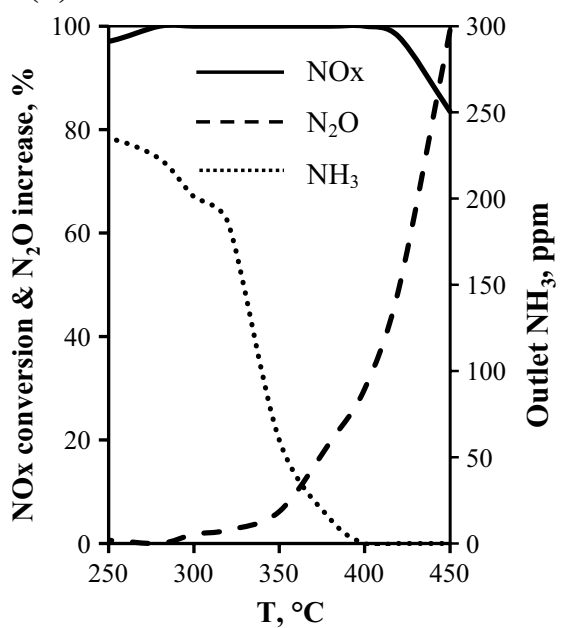

Without reducing agent,

$\mathrm{NO}_{\mathrm{X}}$ concentration at inlet $=1500 \mathrm{ppm}$, NOx concentration at outlet $=1500 \mathrm{ppm}$.

With reducing agent $\left(0.2\right.$ vol. $\left.\% \mathrm{NH}_{3}\right)$, $\mathrm{NO}_{\mathrm{X}}$ concentration at inlet $=1500 \mathrm{ppm}$, NOx concentration at outlet $=0 \mathrm{ppm}$.
$65 \% \mathrm{~N}_{2} \mathrm{O}$ conversion. However, under optimal conditions $\left(F_{\mathrm{GR}}=300 \mathrm{~L} / \mathrm{h}, 5000 \mathrm{GHSV}, T=425-450^{\circ} \mathrm{C}\right)$, the dual-bed catalytic system with reducing agent allows for the complete reduction of $\mathrm{NO}_{x}$ and complete conversion of $\mathrm{N}_{2} \mathrm{O}$ from the tail gases. Despite the possibility of formation of the additional amount of nitrous oxide in $\mathrm{deNO}_{x}$ catalytic bed, at the temperature over $400^{\circ} \mathrm{C}$, no presence of $\mathrm{NO}_{x}, \mathrm{NH}_{3}$ and $\mathrm{N}_{2} \mathrm{O}$ was found in tail gases stream.

The proposed dual-bed catalytic system can be used in the process of $\mathrm{N}_{2} \mathrm{O}$ decomposition from the tail gases, especially in the high- and dual-pressure nitric acid plants. In addition, the $\mathrm{N}_{2} \mathrm{O}$ abatement in the temperature used is a major challenge for low-temperature deNO $\mathrm{N}_{x}$ systems (Yates et al. 2005; Martín et al. 2007). Usually, significantly higher operating parameters are required for an effective course of $\mathrm{N}_{2} \mathrm{O}$ catalytic decomposition compared to the typical temperature of deNO ${ }_{x}$ process. The presented method of the two-stage tail gas purification can be then an attractive solution to this problem. In this case, the system of two catalysts was applied, the effectiveness of which $\left(>400{ }^{\circ} \mathrm{C}\right)$ is sufficient for achieving the residual emissions of $\mathrm{N}_{2} \mathrm{O}, \mathrm{NO}_{x}$ and $\mathrm{NH}_{3}$ close to 0 .

\section{Conclusions}

Activity tests of the supported double-promoted cobalt spinel catalyst carried out in the model gas stream showed a high activity of the developed catalyst. However, during catalytic investigations performed under real industrial conditions it was found that this catalyst is very sensitive to $\mathrm{NO}_{x}$ poisoning.

As a solution, a dual-bed catalytic system was proposed, consisting of the two consecutive catalysts layers, deNO $\mathrm{NO}_{x}$ commercial catalyst $\left(\mathrm{NH}_{3}-\mathrm{SCR}\right)$ and developed $\mathrm{deN}_{2} \mathrm{O}$ catalyst for a successive removal of these nitrogen oxides from the tail gas stream. 
The use of stoichiometric amount or slightly higher amount of ammonia in deNO $\mathrm{NCR}_{x}$ process with respect to the initial concentration of $\mathrm{NO}_{x}$ in the tail gas ensures the complete $\mathrm{NO}_{\mathrm{x}}$ reduction and does not cause ammonia slip. After applying deNO ${ }_{x}$ catalyst bed before the supported double-promoted cobalt spinel catalyst bed (dualbed configuration), a high activity of the developed $\mathrm{deN}_{2} \mathrm{O}$ catalyst was found at temperature range of $425-450{ }^{\circ} \mathrm{C}$.

The proposed dual-bed catalytic system can be used in the process of $\mathrm{N}_{2} \mathrm{O}$ decomposition from the tail gases, especially in the high- and dual-pressure nitric acid plants if sufficiently high temperature of tail gases is ensured.

Acknowledgements This work was supported by NCBiR, Project No. PBS2/A5/38/2013.

\section{Compliance with ethical standards}

Conflict of interest On behalf of all authors, the corresponding author states that there is no conflict of interest.

Open Access This article is distributed under the terms of the Creative Commons Attribution 4.0 International License (http://creativeco mmons.org/licenses/by/4.0/), which permits unrestricted use, distribution, and reproduction in any medium, provided you give appropriate credit to the original author(s) and the source, provide a link to the Creative Commons license, and indicate if changes were made.

\section{References}

Avila P, Barthelemy C, Bahamonde A, Blanco J (1993) Catalyst for $\mathrm{NO}_{x}$ removal in nitric-acid plant gaseous effluents. Atmos Environ Part A Gen Topics 27:443-447. https://doi. org/10.1016/0960-1686(93)90118-I

Cheng DG, Chen F, Zhan X (2012) Characterization of iron-containing AlPO-5 as a stable catalyst for selective catalytic reduction of $\mathrm{N}_{2} \mathrm{O}$ with $\mathrm{CH}_{4}$ in the presence of steam. Appl Catal A 435:27-31. https://doi.org/10.1016/j.apcata.2012.05.027

Directive 2010/75/Eu of the European Parliament and of the Council of 24 November 2010 on industrial emissions (integrated pollution prevention and control). Official Journal of the European Union, Part 3: Air emission limit values for waste incineration plants. L334/68

Grzybek G, Stelmachowski P, Indyka P, Inger M, Wilk M, Kotarba A, Sojka Z (2015) Cobalt-zinc spinel dispersed over cordierite monoliths for catalytic $\mathrm{N}_{2} \mathrm{O}$ abatement from nitric acid plants. Catal Today 257:93-97. https://doi.org/10.1016/j.catto d.2015.02.022

Grzybek G, Wójcik S, Ciura K, Gryboś J, Indyka P, Oszajca M, Stelmachowski P, Witkowski S, Inger M, Wilk M, Kotarba A, Sojka Z (2017) Influence of preparation method on dispersion of cobalt spinel over alumina extrudates and the catalyst de $\mathrm{N}_{2} \mathrm{O}$ activity. Appl Catal B Environ 210:34-44. https://doi. org/10.1016/j.apcatb.2017.03.053

Hussain M, Fino D, Russo N (2012) $\mathrm{N}_{2} \mathrm{O}$ decomposition by mesoporous silica supported Rh catalysts. J Hazard Mater 211:255-265. https://doi.org/10.1016/j.jhazmat.2011.08.024
Inger M, Kowalik P, Saramok M, Stelmachowski P, Sojka Z (2011a) Laboratory and pilot scale synthesis, characterization and reactivity of multicomponent cobalt spinel catalyst for low temperature removal of $\mathrm{N}_{2} \mathrm{O}$ from nitric acid plant tail gases. Catal Today 176(1):365-368. https://doi.org/10.1016/j.catto d.2010.11.044

Inger M, Kowalik P, Saramok M, Wilk M, Stelmachowski P, Maniak G, Granger P, Kotarba A, Sojka Z (2011b) Laboratory and pilot scale synthesis, characterization and reactivity of multicomponent cobalt spinel catalyst for low temperature removal of $\mathrm{N}_{2} \mathrm{O}$ from nitric acid plant tail gases. Catal Today 176:365-368. https ://doi.org/10.1016/j.cattod.2010.11.044

Inger M, Saramok M, Migdal G, Wilk M (2013) Low-temperature reduction of $\mathrm{N}_{2} \mathrm{O}$ emission from tail gases of nitric acid production. Przem Chem 92(12):2237-2240

Inger M, Wilk M, Saramok M, Grzybek G, Grodzka A, Stelmachowski P (2014) Cobalt spinel catalyst for N2O abatement in the pilot plant operation-longterm activity and stability in tail gases. Ind Eng Chem Res 53:10335-10342. https://doi.org/10.1021/ie501 4579

Kapteijn F, Rodrigues-Mirasol J, Moulijn JA (1996) Heterogeneous catalytic decomposition of nitrous oxide. Appl Catal B 1-4:25-64. https://doi.org/10.1016/0926-3373(96)90072-7

Karaskova K, Chromacakova Z, Studentova S, Matejka V, Jiratova K, Obalova L (2012) A comparative study of TiO2-supported and bulk $\mathrm{Co}-\mathrm{Mn}-\mathrm{Al}$ catalysts for $\mathrm{N}_{2} \mathrm{O}$ decomposition. Catal Today 191:112-115. https://doi.org/10.1016/j.cattod.2012.03.046

Karásková K, Obalová L, Jirátová K, Kovanda F (2010) Effect of promoters in $\mathrm{Co}-\mathrm{Mn}-\mathrm{Al}$ mixed oxide catalyst on $\mathrm{N}_{2} \mathrm{O}$ decomposition. Chem Eng J 160:480-487. https://doi.org/10.1016/j. cej.2010.03.058

Kim MK, Kim PS, Baik JH, Nam I (2011) DeNO $_{x}$ performance of $\mathrm{Ag} / \mathrm{Al}_{2} \mathrm{O}_{3}$ catalyst using simulated diesel fuel-ethanol mixture as reductant. Appl Catal B 105:1-14. https://doi.org/10.1016/j. apcatb.2011.03.017

Kim MK, Kim PS, Cho BK, Nam I (2012) Enhanced $\mathrm{NO}_{x}$ reduction and byproduct removal by $(\mathrm{HC}+\mathrm{OHC}) / \mathrm{SCR}$ over multifunctional dual-bed monolith catalyst. Catal Today 184:95-106. https://doi. org/10.1016/j.cattod.2011.11.010

Lietti L, Nova I, Ramis G, Dall'Acqua L, Busca G (1999) Characterization and reactivity of $\mathrm{V}_{2} \mathrm{O}_{5}-\mathrm{MoO}_{3} / \mathrm{TiO}_{2}$ De- $\mathrm{NO}_{x}$ SCR catalysts. J Catal 87:419-435. https://doi.org/10.1006/jcat.1999.2603

Luck F, Roiron J (1989) Selective catalytic reduction of $\mathrm{NO}_{x}$ emitted by nitric acid plants. Catal Today 4:205-218. https://doi. org/10.1016/0920-5861(89)85051-5

Martín JA, Yates M, Ávila P, Suárez S, Blanco J (2007) Nitrous oxide formation in low temperature selective catalytic reduction of nitrogen oxides with $\mathrm{V}_{2} \mathrm{O}_{5} / \mathrm{TiO}_{2}$ catalysts. Appl Catal B 70:330-334. https://doi.org/10.1016/j.apcatb.2005.11.026

Melian-Cabrera I, Espinosa S, Mentruit C, Moulijn B, Falco L (2018) Overcoming the engineering constraints for scaling-up the stateof-the-art catalyst for tail-gas $\mathrm{N}_{2} \mathrm{O}$ decomposition. Ind Eng Chem Res 57(3):939-945. https://doi.org/10.1021/acs.iecr.7b04584

Pasha N, Lingaiah N, Reddy PSS, Prasad PS (2009) Direct decomposition of $\mathrm{N}_{2} \mathrm{O}$ over cesium-doped $\mathrm{CuO}$ catalysts. Catal Lett 127:101-106. https://doi.org/10.1007/s10562-008-9641-z

Pérez-Ramirez J, García-Cortés JM, Kapteijn F, Illán-Gómez MJ (2000) Dual-bed catalytic system for $\mathrm{NO}_{x}-\mathrm{N}_{2} \mathrm{O}$ removal: a practical application for lean-burn deNO ${ }_{x} \mathrm{HC}-\mathrm{SCR}$. Appl Catal B 25:191-203. https://doi.org/10.1016/S0926-3373(99)00131-9

Pérez-Ramirez J, Kapteijn F, Schoffel K, Moulijn JA (2003) Formation and control of $\mathrm{N}_{2} \mathrm{O}$ in nitric acid production: where do we stand 
today? Appl Catal B 44:117-151. https://doi.org/10.1016/S0926 -3373(03)00026-2

Rico-Pérez V, Bueno-López A (2014) Effect of $\mathrm{RhO}_{\mathrm{x}} / \mathrm{CeO}_{2}$ Calcination on metal-support interaction and catalytic activity for $\mathrm{N}_{2} \mathrm{O}$ decomposition. Appl Sci 4:468-481. https://doi.org/10.3390/ app4030468

Shen Q, Li L, Tian H, Hao Z (2009) A study on $\mathrm{N}_{2} \mathrm{O}$ catalytic decomposition over $\mathrm{Co} / \mathrm{MgO}$ catalysts. J Hazard Mater 163:1332-1337. https://doi.org/10.1016/j.jhazmat.2008.07.104

Wang J, Cui H, Dong X, Zhao H, Wang Y (2015) $\mathrm{N}_{2} \mathrm{O}$ formation in the selective catalytic reduction of $\mathrm{NO}_{x}$ with $\mathrm{NH}_{3}$ on a $\mathrm{CeMoO}_{x}$ catalyst. Appl Catal A 505:8-15. https://doi.org/10.1016/j.apcat a.2015.07.030

Wilk M, Inger M, Prokop U, Sojka Z, Kotarba A, Adamski A, Piskorz W, Zasada F, Stelmachowski P (2009) Catalytic agent for low temperature decomposition of dinitrogen monoxide. Patent PL 213796 B 1

Wilk M, Inger M, Ruszak M, Saramok M, Kowalik P, Antoniak-Jurak K, Sojka Z, Kotarba A, Grzybek G, Stelmachowski P, Gudyka S, Indyka P (2016) Supported Co-Zn spinel catalyst for the abatement of nitrogen(I) oxide emissions especially from nitric acid

\section{Affiliations}

\section{Marek Inger $^{1} \cdot$ Jakub Rajewski $^{1}$ (D) Monika Ruszak ${ }^{1} \cdot$ Marcin Wilk $^{1}$}

Jakub Rajewski

jakub.rajewski@ins.pulawy.pl plants and a method for its manufacture. Patent Application EP3078419 (A1)

Yates M, Martín JA, Martín-Luengo MA, Suárez S (2005) $\mathrm{N}_{2} \mathrm{O}$ formation in the ammonia oxidation and in the SCR process with $\mathrm{V}_{2} \mathrm{O}_{5}-\mathrm{WO}_{3}$ catalysts. Catal Today 107-108:120-125. https://doi. org/10.1016/j.cattod.2005.07.015

Zabilskiy M, Djinović P, Tchernychova E (2015) Nanoshaped CuO/ $\mathrm{CeO}_{2}$ materials: effect of the exposed ceria surfaces on catalytic activity in $\mathrm{N}_{2} \mathrm{O}$ decomposition reaction. ACS Catal 5:5365-5375. https://doi.org/10.1021/acscatal.5b01044

Zhang X, Shen Q, He C, Ma C, Chenh J, Hao Z (2012) $\mathrm{N}_{2} \mathrm{O}$ catalytic reduction by $\mathrm{NH}_{3}$ over Fe-zeolites: effective removal and active site. Catal Commun 18:151-155. https://doi.org/10.1016/j.catco m.2011.11.029

Publisher's Note Springer Nature remains neutral with regard to jurisdictional claims in published maps and institutional affiliations.
1 New Chemical Syntheses Institute, al. Tysiąclecia Państwa Polskiego 13a, 24-110 Puławy, Poland 